\title{
PENGARUH ROA, EPS, DER, NPM TERHADAP RETURN SAHAM (STUDI KASUS PADA PERUSAHAAN PERTAMBANGAN BATUBARA YANG TERDAFTAR DI BURSA EFEK INDONESIA PERIODE 2017-2019)
}

\author{
Sonia Gandhi ${ }^{1)}$, Mellinda ${ }^{2)}$ \\ Fakultas Ekonomi, Universitas Prima Indonesia \\ gandhisonia2304@gmail.com ${ }^{1}, \underline{\text { mellinda@gmail.com }}{ }^{2}$
}

\begin{abstract}
This research was conducted on coal mining companies listed on the Indonesia Stock Exchange (IDX). The purpose of this research is to test and analyze the influence of Return On Assets (ROA), Earning PerShare (EPS), Debt to Equity Ratio(DER) and Net Profit Margin (NPM) on Share Return on coal mining companies listed on the Indonesia Stock Exchange in the period 2017-2019 either in a partial or simultaneous manner. The data in this company is secondary data obtained from the Indonesia Stock Exchange (IDX). There is a population in this study obtained from coal mining companies. There are 54 samples of issuers' financial statements using puposive sampling techniques. The results showed that : Return on Assets has a calculated $t$ value of $<$ t table, $0.466<1.99254$ which means that Return on Assets is partially insignificant and insignificant in the disclosure of a company's Share Return. Earning Per Share has a calculated value of $-t>-t$ table, $-0.658>-1.99254$ which means that Earning Per Share is partially insignificant and insignificant in the disclosure of a company's Share Return. Debt to Equity Ratio has a calculated $t$ value of $>t$ table, -3,784 > -1.99254 which means that Debt to Equity Ratio is partially influential and significant in the disclosure of a company's Share Return. Net Profit Margin has a calculated $t$ value of $>t$ table, 4,483 > 1.99254 which means that Net Profit Margin is partially influential and significant in the disclosure of a company's Share Return. Return on Assets, Earning Per Share, Debt to Equity Ratio, Net Profit Margin simultaneously affects Stock Return.
\end{abstract}

Keywords: ROA, EPS, DER, NPM, and Return stock

\section{PENDAHULUAN}

Setiap perilaku dari perdagangan saham dapatkan menentukan pola perilaku harga saham. Laporan keuangan pada suatu perusahaan bisa menjadi media untuk para investor mengestimasi harga saham suatu perusahaan. Pada penelitian berikut ini menggunakan rasio yang digunakan untuk menggambarkan tingkat pengembalian saham yaitu rasio profitabilitas menggunakan Return On Asset (ROA), rasio solvabilitas menggunakan Debt to Equity Ratio (DER) dan rasio pasar dengan menggunakan Earning per Share (EPS) dan Net Profit Margin (NPM). Return on Asset menggambarkan sejauh mana kemampuan aset-aset yang dimiliki perusahaan bisa menghasilkan laba (Eduardus Tandelilin 2010:372). Semakin besar nilai ROA, menunjukkan kinerja perusahaan yang semakin baik pula, karena tingkat pengembalian investasisemakin besar.

Earning per Share merupakan rasio yang menunjukkan bagian laba untuk setiap saham. Makin tinggi nilai EPS tentu saja menggembirakan pemegang saham karena makin besar laba yang disediakan untuk pemegang saham dan kemungkinan peningkatan jumlah deviden yang diterima pemegang saham (Darmadji dan Fakhruddin 2012:154). Hal ini akan berdampak pada kenaikan harga saham diikuti dengan tingkat pengembalian return yang tinggi. Debt to equity ratio merupakan rasio yang digunakan untuk menilai hutang dengan ekuitas. Rasio ini dicari dengan cara membandingkan antara seluruh hutang, termasuk hutang lancar dengan seluruh ekuitas. Rasio ini digunakan untuk mengetahui jumlah dana yang disediakan peminjam (kreditor) dengan pemilik perusahaan. 
Net profit margin yang semakin tinggi menunjukkan bahwa semakin meningkat keuntungan bersih yang dicapai perusahaan. Dengan meningkatnya NPM maka akan meningkatnya daya tarik investor untuk menanamkan saham perusahaan juga cenderung akan meningkat. Maka apabila NPM meningkat juga akan berpengaruh terhadap return saham. Penelitian tentang return saham telah banyak dilakukan megingat pentingnya pengaruh dari faktor fundamental terhadap nilai return saham. Return saham adalah tingkat keuntungan yang dinikmati oleh pemodal atas suatu investasi yang dilakukan (Robert Ang, 2001).

\section{KAJIAN LITERATUR}

\section{Return On Asset (ROA)}

Menurut Kasmir (2014), ROA adalah menunjukkan hasil (return) atas jumlah aktiva yang digunakan dalam perusahaan. Selain itu, ROA memberikan ukuran yang lebih baik atas profitabilitas perusahaan karena menunjukkan efektivitas manajemen dalam menggunakan aktiva untuk memperoleh pendapatan. Meningkatnya nilai perusahaan akan semakin baik dan dapat menarik perhatian para investor untuk membeli saham perusahaan, sehingga akan berpengaruh pada perubahan harga saham di pasar modal.

$$
\mathrm{ROA}=\frac{\text { Laba Bersih } \times 100 \%}{\text { Total Aktiva }}
$$

\section{Earning Per Share}

Menurut Fahmi (2012), Earning Per Share (EPS) atau pendapatan saham perlembar adalah bentuk pemberian keuntungan yang diberikan kepada para pemegang saham dari setiap lembar saham dimiliki. Seorang investor membeli dan mempertahankan saham suatu perusahaan dengan harapan akan memperoleh deviden atau capital gain.

$$
\text { EPS }=\frac{\text { Laba Bersih }}{\text { Jumlah Saham yang Beredar }}
$$

\section{Debt to Equity Ratio}

Debt to Equity Ratio merupakan ukuran yang dipakai dalam menganalisis laporan keuangan untuk memperlihatkan besarnya jaminan yang tersedia untuk kreditor. Menurut Kasmir (2014) semakin tinggi Debt ratio maka akan semakin besar resiko yang dihadapi, dan investor akan meminta tingkat keuntungan yang semakin tinggi. Rasio yang tinggi menunjukkan proporsi modal sendiri yang rendah untuk membiayai aktiva. Hal ini akan direspon negatif oleh para investor di pasar modal.

$$
\text { DER }=\frac{\text { Total Utang }}{\text { Ekuitas }}
$$

\section{Net Profit Margin}

Net Profit Margin (NPM) bertujuan untuk mengetahui secara langsung keuntungan bersihnya. Semakin besar nilai NPM akan semakin baik karena perusahaan mampu menghasilkan laba bersih yang tinggi, hal tersebut akan menarik minat investor untuk memiliki saham perusahaan yang nantinya dapat meningkatkan return saham di masa yang akan datang (Mahardika dan Artini, 2017). 


$$
\text { NPM }=\frac{\text { Laba Bersih }}{\text { Sales }}
$$

\section{Return saham}

Menurut Gitman (2010: 228) Return saham merupakan tingkat pengembalian untuk saham biasa dan merupakan pembayaran kas yang diterima akibat kepemilikan suatu saham pada saat awal investasi.

$$
\text { Return Saham }=\frac{\mathrm{P}_{\mathrm{t}}-\mathrm{P}_{(\mathrm{t}-1)}}{\mathrm{P}_{(\mathrm{t}-1)}}
$$

\section{Teori Pengaruh Return On Asset terhadap Return Saham}

Menurut Kasmir (2014), ROA adalah menunjukkan hasil (return) atas jumlah aktiva yang digunakan dalam perusahaan. Selain itu, ROA memberikan ukuran yang lebih baik atas profitabilitas perusahaan karena menunjukkan efektivitas manajemen dalam menggunakan aktiva untuk memperoleh pendapatan. Meningkatnya nilai perusahaan akan semakin baik dan dapat menarik perhatian para investor untuk membeli saham perusahaan, sehingga akan berpengaruh pada perubahan harga saham di pasar modal.

Menurut Diaz dan Jufrizen (2014) ROA adalah tingkat pengembalian atau laba yang dihasilkan atas pengelolaan aset ataupun investasi perusahaan. Rasio ini memberikan pengukuran atas efektivitas perusahaan karena memperhitungkan penggunaan aktiva dan profitabilitas dalam penjualan disuatu perusahaan. Menurut Husnan (2010:78) ROA menyatakan berapa besar profit yang mampu dihasilkan ialah setiap rupiah aset yang ditanam atau diinvestasikan. ROA merupakan salah satu rasio probabilitas yang mengukur efektivitas perusahaan dalam menghasilkan keuntungan dengan memanfaatkan aktiva yang dimiliki nya. Indikator ROA merupakan salah satu indikator keuangan yang sering digunakan dalam menilai kinerja perusahaan, jika kinerja perusahaan tersebut semakin baik, maka tingkat pengembalian (retrun) semakin besar.

\section{Teori Pengaruh Earning Per Share terhadap Return Saham}

Menurut Fahmi (2012), Earning Per Share (EPS) atau pendapatan saham perlembar adalah bentuk pemberian keuntungan yang diberikan kepada para pemegang saham dari setiap lembar saham dimiliki. Seorang investor membeli dan mempertahankan saham suatu perusahaan dengan harapan akan memperoleh deviden atau capital gain.

Menurut Widoatmodjo dan Priatinah (2012), EPS sangat berpengaruh terhadap harga saham. Semakin tinggi EPS maka akan semakin mahal suatu saham, karena EPS merupakan salah satu bentuk rasio keuangan untuk menilai kinerja perusahaan.

\section{Teori Debt to Equity Ratio terhadap Return Saham}

Debt to Equity Ratio merupakan ukuran yang dipakai dalam menganalisis laporan keuangan untuk memperlihatkan besarnya jaminan yang tersedia untuk kreditor. Menurut Kasmir (2014) semakin tinggi Debt ratio maka akan semakin besar resiko yang dihadapi, dan investor akan meminta tingkat keuntungan yang semakin tinggi. Rasio yang tinggi menunjukkan proporsi modal sendiri yang rendah untuk membiayai aktiva. Hal ini akan direspon negatif oleh para investor di pasar modal.

Menurut Ross et al. (2000), Perusahaan yang memiliki DER yang tinggi dapat memberi laba yang besar kepada pemegang saham jika perusahaan menggunakan utang sebagai dana untuk meningkatkan penjualan dan pendapatan. Dengan meningkatnya laba, investor akan tertarik untuk menanamkan modalnya pada perusahaan. Oleh karena itu, DER 4yang tinggi sangat mempengaruhi peningkatan retrun saham.

\section{Teori Net Profit Margin terhadap Return Saham}

Net Profit Margin (NPM) bertujuan untuk mengetahui secara langsung keuntungan bersihnya. Semakin besar nilai NPM akan semakin baik karena perusahaan mampu menghasilkan laba bersih yang 
tinggi, hal tersebut akan menarik minat investor untuk memiliki saham perusahaan yang nantinya dapat meningkatkan return saham di masa yang akan datang (Mahardika dan Artini, 2017).

Net Profit Margin menunjukan perbandingan antara laba bersih dengan penjualan (Hanafi dan Halim, 2005). Rasio ini digunakan untuk menghitung sejauh mana kemampuan perusahaan yang bersangkutan dalam menghasilkan laba bersih ditinjau dari sudut penjualannya. Dengan demikian para investor atau calon investor lain akan tertarik untuk menanamkan dana kedalam perusahaan tersebut.

\section{Kerangka Konseptual}

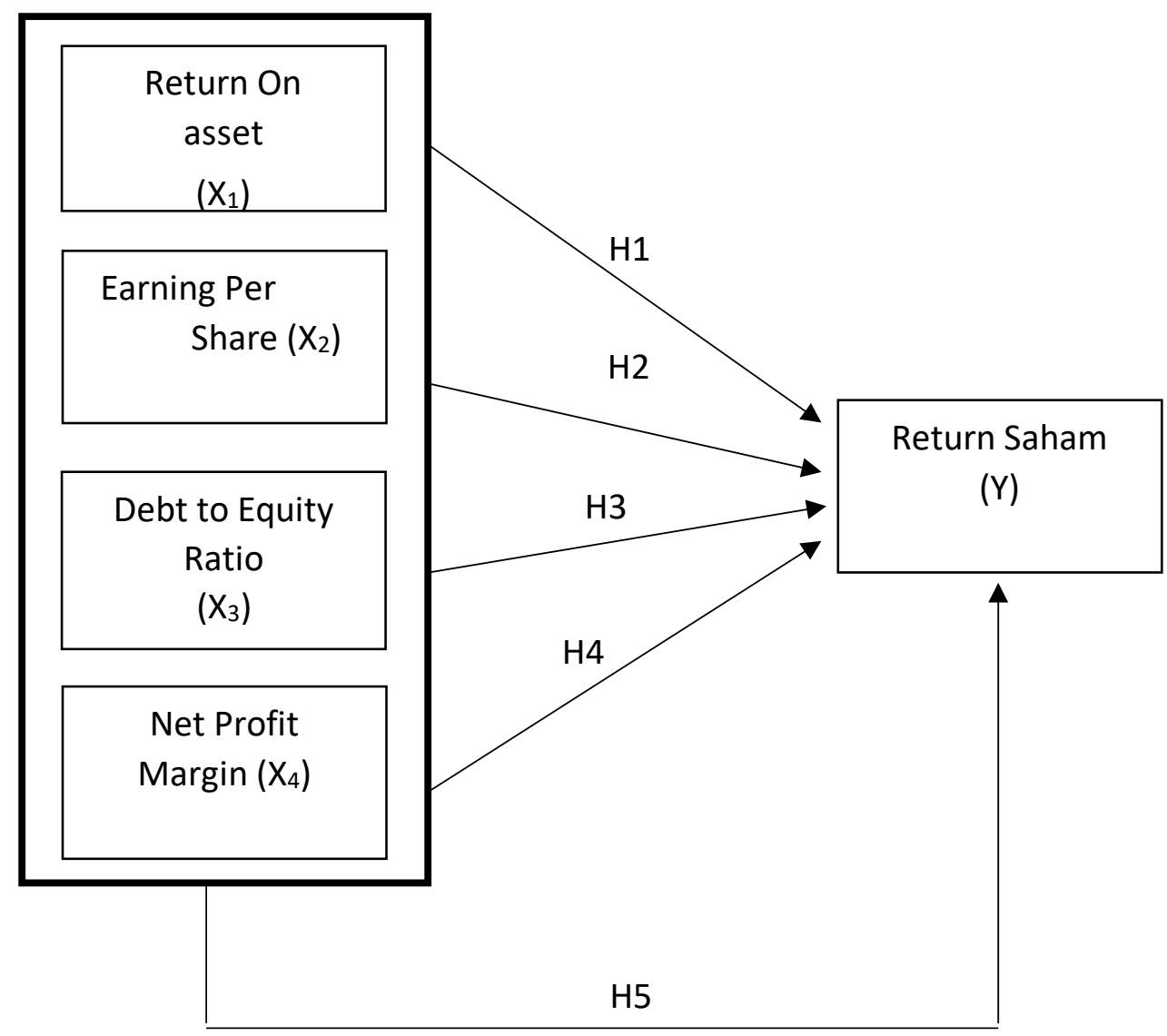

Gambar 1. Kerangka Konseptual

\section{METODE}

Metode penelitian ini dilakukan pada perusahaan pertambagan batu bara yang terdaftar di Bursa Efek Indonesia periode 2017-2019. Penelitian ini menggunakan metode penelitian kuantitatif.

\section{Jenis Penelitian}

Menurut Sugiyono (2003: 11). Penelitian diskriptif adalah penelitian yang dilakukan untuk mengetahui nilai variabel mandiri, baik satu variabel atau lebih (independen) tanpa membuat perbandingan, atau menghubungkan dengan variabel yang lain.

\section{Sifat Penelitian}

Sifat penelitian yang digunakan adalah adanya hubungan sebab akibat (kausal), sehingga dalam penelitiannya ada variabel independen dan dependen. (Sugiyono, $2017: 11$ ). 


\section{Populasi dan Sampel}

Menurut Sugiyono (2017:115) populasi adalah wilayah generalisasi yang terdiri atas sebuah obyek atau subyek yang memiliki kualitas dan karakteristik tertentu yang akan ditetapkan oleh peneliti untuk dipelajari dan kemudian ditarik hasil kesimpulannya. Jenis pemilihan sampel dalam penelitian ini adalah dengan metode purposive sampling. Dalam penelitian ini, kriteria yang ditetapkan dalam penentuan sample adalah:

1. Perusahaan Pertambangan Subsektor Batubara yang tidak terdaftar di Bursa Efek Indonesia 20172019.

2. Perusahaan Pertambangan Subsektor Batubara yang tidak melaporkan laporan keuangan secara berturut-turut selama periode 2017-2019.

3. Perusahaan Pertambangan Subsektor Batubara yang tidak mengalami kerugian selama periode 2017-2019.

Sesuai dengan penarikan sampel dengan tehnik purposive sampling pada 25 perusahaan yang terdaftar di BEI selama periode 2017 - 2019 , jumlah sampel yang dipakai adalah sebanyak 18 perusahaan dengan jumlah sampel yang dikalikan dengan 3 tahun periodenya yaitu sebanyak 54 sampel.

\section{Jenis dan Sumber Data Penelitian}

Jenis penilitian yang digunakan dalam penelitian ini adalah penelitian kuantitatif. Menurut Sugiono (2017:8), metode kuantitatif adalah metode penelitian yang digunakan dalam meneliti pada populasi sampel tetentu, pengumpulan data menggunakan instrumen penelitian, analisis data bersifat kuantitatif/statistik, dengan tujuan untuk menguji hipotesis yang telah ditetapkan.

\section{Uji Asumsi Klasik}

Uji asumsi klasik adalah pengujian terhadap data yang berguna untuk mengetahui apakah data penelitian sudah memenuhi ketentuan model regresi.

\section{Uji Normalitas}

Menurut Ghozali (2016) uji normalitas dilakukan untuk menguji apakah pada suatu model regresi, suatu variabel independen dan variabel dependen ataupun keduanya mempunyai distribusi normal atau tidak normal.

\section{Uji Multikolonieritas}

Menurut Ghozali (2012: 105) uji multikolinearitas bertujuan untuk menguji apakah suatu model regresi terdapat korelasi antar variabel bebas (independen). Model regresi yang baik seharusnya tidak terjadi korelasi antar variabel independen.

\section{Uji Autokorelasi}

Menurut Ghozali (2018:111) uji autokorelasi dilakukan untuk menguji apakah dalam model regresi linear ada korelasi antara kesalahan penggangu pada periode $t$ dengan kesalahan pengganggu pada periode $t-$ 1 (sebelumnya).

\section{Uji Heteroskedastisitas}

Menurut Ghozali (2018:137) uji heteroskedastisitas dilakukan untuk menguji apakah dalam model regresi terjadi ketidaksamaan variance dari residual satu pengamatan kepengamatan yang lain.

\section{Teknik Analisis Data}

Analisis statistik yang digunakan untuk pengujian hipotesis dalam penelitian ini yaitu analisis regresi linear berganda dengan terlebih dahulu melakukan uji asumsi klasik. Uji asumsi klasik dilakukan dengan uji normalitas data, multikolinearitas, autokorelasi, heterokedasitas. 


\section{Uji Signifikan Secara Simultan (Uji-F)}

Uji-F adalah uji statistik di mana statistik uji memiliki distribusi-F di bawah hipotesis nol. Ini paling sering digunakan saat membandingkan model statistik yang telah dipasang ke kumpulan data, untuk mengidentifikasi model yang paling sesuai dengan populasi dari mana data dijadikan sampel.

\section{Uji Signifikan Secara Parsial (Uji - t)}

Uji t dikenal dengan uji parsial, yaitu untuk menguji bagaimana pengaruh masing-masing variabel bebasnya secara sendiri-sendiri terhadap variabel terikatnya.

\section{HASIL DAN PEMBAHASAN}

\section{Analisis Regresi Linear Berganda}

Analisis ini digunakan untuk melihat hubungan antara masing masing variabelindependen dengan variabel dependen. Hasil analisi regresi linear berganda dapat dilihat dari tabel dibawah ini :

Tabel 1. Regresi Linear Berganda

\begin{tabular}{|cl|l|l|l|l|}
\hline \multirow{2}{*}{ Model } & & \multicolumn{2}{|c|}{ Unstandardized Coefficients } & \multicolumn{2}{c|}{ Collinearity Statistics } \\
\cline { 3 - 6 } & & $\mathrm{B}$ & Std. Error & Tolerance & VIF \\
\hline 1 & (Constant) & -1.312 & .373 & & \\
& ROA & .018 & .039 & .799 & 1.252 \\
& EPS & -.071 & .108 & .784 & 1.275 \\
& DER & -.047 & .013 & .793 & 1.261 \\
& NPM & .005 & .001 & .837 & 1.194 \\
\end{tabular}

Dependent Variable: RETURN SAHAM

Persamaan regresi linear berganda yang dihasilkan yaitu :

$$
\mathrm{Y}=-1,312+0,018 \mathrm{ROA}-0,071 \mathrm{EPS}+\text { 0,047 DER - 0,005 NPM }
$$

Hasil persamaan menunjukkan bahwa ROA dan NPM memiliki koefisien positif. Hal ini menunjukkan bahwa jika terjadi peningkatan pada ROA, EPS, DER, dan NPM maka akan meningkatkan pengungkapan Return Saham suatu perusahaan. Di sisi lain EPS memiliki koefisien negatif dimana jika terjadi peningkatan pada EPS maka akan meningkat pengungkapan Return Saham suatu perusahaan. Dan disisi lain DER memiliki koefisien negatif dimana jika terjadi peningkatan pada DER maka akan meningkatkan pengungkapan Return Saham.

\section{Uji Asumsi Klasik Uji Normalitas}

Uji Normalitas adalah uji yang dilakukan untuk menilai apakah sebaran data pada variabel bebas dan terikat berdistribusi secara normal. Dalam penelitian ini menggunakan uji Kolmogorov - Smirnov Z dengan hasil sebagai berikut : 
Tabel 2. One-Sample Kolmogorov-Smirnov Test

\begin{tabular}{|c|c|c|}
\hline & & $\begin{array}{l}\text { Unstandardi } \\
\text { zed } \\
\text { Residual }\end{array}$ \\
\hline $\mathrm{N}$ & & 80 \\
\hline \multirow[t]{2}{*}{ Normal Parameters ${ }^{\mathrm{a}, \mathrm{b}}$} & Mean & .0000000 \\
\hline & Std. Deviation & 12032875 \\
\hline \multirow{3}{*}{$\begin{array}{l}\text { Most } \\
\text { Differences }\end{array}$} & Absolute & .090 \\
\hline & Positive & .090 \\
\hline & Negative & -.070 \\
\hline Kolmogorov-Smirnov Z & & .808 \\
\hline Asymp. Sig. (2-tailed) & & .531 \\
\hline
\end{tabular}
a. Test distribution is
Normal.
b. Calculated from data.

Hasil Asymp sig (2-tailed) menunjukkan nilai sebesar 0,531 dimana hasil tersebut lebihbesar dari 0,05 sehingga model regresi penelitian ini memenuhi asumsi normalitas.

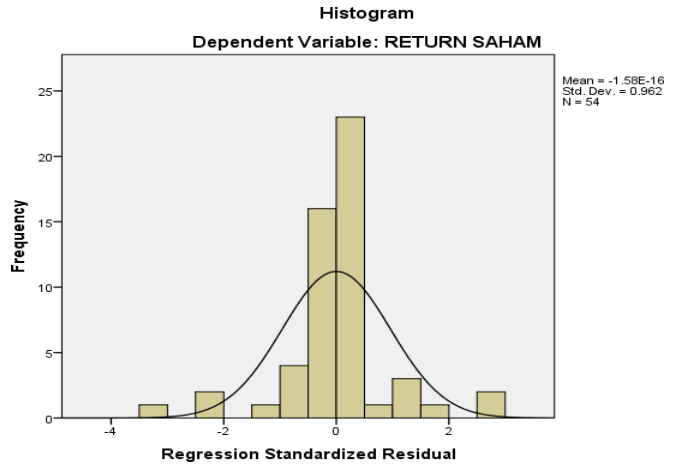

Gambar 2. Normalitas 
Grafik histogram diatas menghasilkan kurva beraturan yang menandakan bahwa modelregresi penelitian ini memenuhi asumsi normalitas.

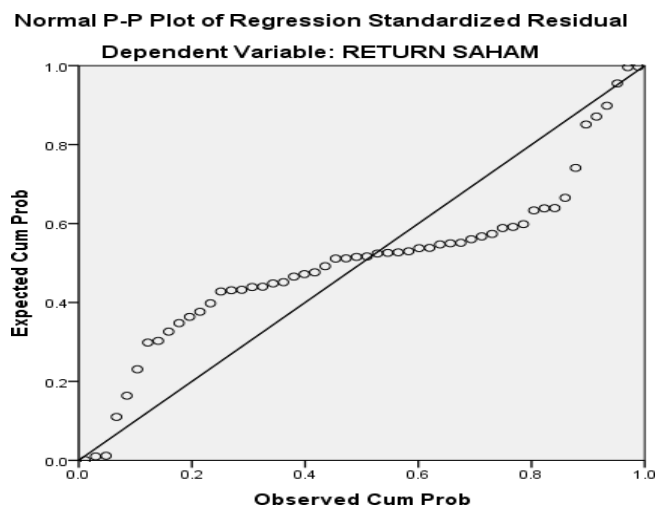

Gambar 3. Grafik P-P Plot

Berdasarkan titik pada normal P-P Plot menunjukkan bahwa titik titik menyebar pada sekitar garis diagonal dan mengikuti arah garis diagonal yang menujukkan bahwa model regresi penelitian ini memenuhi asumsi normalitas.

\section{Uji Multikolinearitas}

Uji Multikolinearitas adalah uji yang dilakukan untuk memastikan dalam suatu regresi tidak terdapat kolinearitas antar variabel bebas. Model regresi yang baik adalah tidak terjadinya multikolinearitas antara variabel bebas.

Tabel 3. Multikolinearitas

\begin{tabular}{|c|c|c|c|c|c|}
\hline \multirow{2}{*}{\multicolumn{2}{|c|}{ Model }} & \multirow{2}{*}{$\mathrm{T}$} & \multirow{2}{*}{ Sig. } & \multicolumn{2}{|c|}{$\begin{array}{l}\text { Collinearity } \\
\text { Statistics }\end{array}$} \\
\hline & & & & Tolerance & VIF \\
\hline \multirow[t]{5}{*}{1} & (Constant) & -3.512 & .001 & & \\
\hline & ROA & .466 & .643 & .799 & 1.252 \\
\hline & EPS & -.658 & .513 & .784 & 1.275 \\
\hline & DER & -3.784 & .000 & .793 & 1.261 \\
\hline & NPM & 4.483 & .000 & 837 & 1.194 \\
\hline
\end{tabular}

Dependent Variable: RETURN SAHAM

Hasil analisis menujukkan bahwa nilai tolerance dari masing-masing variabel bebas $>0,01$ dan nilai VIF $<10$. Dari hasil tersebut memiliki arti bahwa tidak terjadinya multikolinearitas antar variabel bebas. 


\section{Uji Autokorelasi}

Uji Autokorelasi adalah uji yang dilakukan untuk mengetahui apakah ada korelasi antar variabel dengan perubahan waktu. Model regresi yang baik adalah tidak terjadinya autokorelasi.

Tabel 4. Model Summary ${ }^{b}$

\begin{tabular}{|c|c|c|c|c|c|}
\hline Model & $\mathrm{R}$ & R Square & $\begin{array}{c}\text { Adjusted } \\
\text { R } \\
\text { Square }\end{array}$ & $\begin{array}{l}\text { Std. Error of } \\
\text { the } \\
\text { Estimate }\end{array}$ & Durbin-Watson \\
\hline 1 & $\begin{array}{l}.570 \\
\mathrm{a}\end{array}$ & 324 & .279 & $\begin{array}{l}.12432 \\
7\end{array}$ & 2.029 \\
\hline
\end{tabular}

a. Predictors: (Constant), ROA,EPS,DER,dan NPM

b. Dependent Variable: RETURN SAHAM

\section{Uji Heterokedastisitas}

Uji Heterokedastisitas adalah uji yang mengetahui apakah dalam suatu regresi terdapat ketidaksamaan varians residual suatu pengamatan ke pengamatan lainnya.

Tabel 5. Heterokedasitas

\begin{tabular}{|c|c|c|c|c|c|}
\hline \multirow{2}{*}{\multicolumn{2}{|c|}{ Model }} & \multirow[b]{2}{*}{$\mathrm{T}$} & \multirow[b]{2}{*}{ Sig. } & \multicolumn{2}{|c|}{ Collinearity Statistics } \\
\hline & & & & Tolerance & VI \\
\hline \multirow[t]{5}{*}{1} & (Constant) & -2.153 & .039 & & \\
\hline & ROA & -.497 & .622 & .812 & 1.232 \\
\hline & EPS & 1.224 & .230 & .692 & 1.446 \\
\hline & DER & -1.356 & .184 & .581 & 1.721 \\
\hline & NPM & .718 & .478 & .774 & 1.292 \\
\hline
\end{tabular}

Dependent Variable: RETURN SAHAM

Dari hasil analisis menunjukkan bahwa semua variabel bebas memiliki nilai signifikan $>0,05$, yang dapat diartikan tidak terjadi gejala heterokedastisitas. 


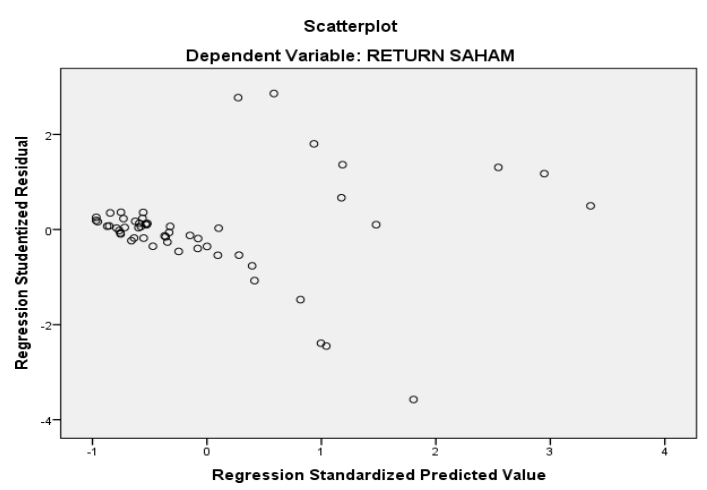

Gambar 4. Scatterplot

Berdasarkan output Scatterplot diatas menunjukkan bahwa titik titik menyebar dan titik membentuk suatu pola tertentu yang diartikan bahwa tidak terdapat gejala heterokedastisitas.

\section{Uji koefisien determinasi $\left(\mathbf{R}^{2}\right)$}

Tabel 6. Model Summary ${ }^{b}$

\begin{tabular}{|c|c|c|c|c|c|}
\hline Model & $\mathrm{R}$ & R Square & $\begin{array}{l}\text { Adjusted } \\
\text { R } \\
\text { Square }\end{array}$ & $\begin{array}{l}\text { Std. Error of } \\
\text { the } \\
\text { Estimate }\end{array}$ & Durbin-Watson \\
\hline 1 & $\begin{array}{l}.570 \\
\mathrm{a}\end{array}$ & .324 & .279 & $\begin{array}{l}.12432 \\
7\end{array}$ & 2.029 \\
\hline
\end{tabular}

a. Predictors: (Constant), ROA,EPS,DER,dan NPM

b. Dependent Variable: RETURN SAHAM

Dari hasil analisis diperoleh Adjustef $\mathrm{R}^{2}$ Square sebesar 0,279 atau 27,9\%. Hal inimenunjukkan bahwa ROA, EPS, DER dan NPM memiliki nilai sebesar 27,9\% dalam mempengaruhi pengungkapan Return Saham sedangkan sisanya sebesar 72,1\% dipengaruhi olehvariabel lain.

\section{Uji Simultan (Uji F)}

Uji $\mathrm{F}$ adalah yang digunakan untuk melihat apakah variabel bebas secara bersamaan mempengaruhi variabel terikat. Nilai uji $\mathrm{F}$ digunakan untuk menguji keberartian model regresi yang digunakan. Uji F juga akan berhubungan dengan uji ANAVA dan ANOVA. 
Tabel 7. ANOVA

\begin{tabular}{|ll|ll|l|l|l|c|}
\hline Model & & $\begin{array}{l}\text { Sum } \\
\text { Squares }\end{array}$ & of & $\begin{array}{l}\mathrm{D} \\
\mathrm{f}\end{array}$ & Mean Square & F & Sig. \\
\hline 1 & Regression & 549 & 5 & .110 & $\begin{array}{l}7.11 \\
0\end{array}$ & $\begin{array}{l}.000 \\
\mathrm{a}\end{array}$ \\
& $\begin{array}{l}\text { Residual } \\
\text { Total }\end{array}$ & 1.144 & 74 & .015 & & \\
\hline
\end{tabular}

a. Predictors: (Constant), ROA, EPS, DER, dan NPM

b. Dependent Variable: RETURN SAHAM

Berdasarkan hasil analisis yang diperoleh bahwa nilai $\mathrm{F}$ adalah 7,110 . Berdasarkan tabel $\mathrm{F}$ yang digunakan dengan signifikansi 0,05, menunjukkan bahwa nilai $\mathrm{F}$ hitung $>\mathrm{F}$ Tabel, 7,110 $>$ 2,34 yang memiliki arti ROA, EPS, DER, dan NPM secara simultan berpengaruh signifikan dalam pengungkapan Return Saham suatu perusahaan.

\section{Uji Parsial (Uji t)}

Uji $t$ adalah uji yang digunakan untuk menilai apakah variabel bebas secara parsial berpengaruh terhadap variabel bebas. Setiap nilai $t$ hasil perhitungan, akan dibandingkan dengan $t$ tabel yang digunakan yang didapatkan menggunakan taraf nyata (biasanya 0,05 ).

Tabel 8.Uji T

\begin{tabular}{|c|c|c|c|c|c|}
\hline \multirow{2}{*}{\multicolumn{2}{|c|}{ Model }} & \multirow{3}{*}{$\frac{t}{-3.512}$} & \multirow{3}{*}{$\frac{\text { Sig. }}{.001}$} & \multicolumn{2}{|c|}{ Collinearity Statistics } \\
\hline & & & & Tolerance & VIF \\
\hline \multirow[t]{5}{*}{1} & (Constant) & & & & \\
\hline & $\mathrm{ROA}$ & 466 & .643 & .799 & 1.252 \\
\hline & EPS & -.658 & .513 & .784 & 1.275 \\
\hline & DER & -3.784 & .000 & .793 & 1.261 \\
\hline & NPM & 4.483 & .000 & .837 & 1.194 \\
\hline
\end{tabular}

Dependent Variable: RETURN SAHAM

Berdasarkan hasil analisis tersebut menggunakan tabel $t$ dengan signifikansi 0,05 diperoleh:

1. Return on Assets memiliki nilai t hitung $<\mathrm{t}$ tabel, 0,466 < 1,99254 yang memiliki arti bahwa Return on Assets s secara parsial tidak berpengaruh dan tidak signifikan dalam pengungkapan Return Saham suatu perusahaan.

2. Earning Per Share memiliki nilai -t hitung $>-t$ tabel, $-0,658>-1,99254$ yang memiliki arti bahwa Earning Per Share secara parsial tidak berpengaruh dan tidak signifikan dalam pengungkapan Return Saham suatu perusahaan.

3. Debt to Equity Ratio memiliki nilai thitung $>\mathrm{t}$ tabel,- 3,784 $>-1,99254$ yang memiliki arti bahwa Debt to Equity Ratio secara parsial berpengaruh dan signifikan dalam pengungkapan Return Saham suatu perusahaan. 
4. Net Profit Margin memiliki nilai t hitung $>\mathrm{t}$ tabel, 4,483 > 1,99254 yang memiliki arti bahwa Net Profit Margin secara parsial berpengaruh dan signifikan dalam pengungkapanReturn Saham suatu perusahaan.

\section{KESIMPULAN}

Berdasarkan penelitian yang telah dilakukan menunjukkan bahwa Return on Assets secara parsial tidak berpengaruh dan tidak signifikan dalam pengungkapan Return Saham suatu perusahaan. Earning Per Share secara parsial tidak berpengaruh dan tidak signifikan dalam pengungkapan Return Saham suatu perusahaan. Debt to Equity Ratio secara parsial berpengaruh dan signifikan dalam pengungkapan Return Saham suatu perusahaan. Net Profit Margin secara parsial berpengaruh dan signifikan dalam pengungkapan Return Saham suatu perusahaan. Return on Assets, Earning Per Share, Debt to Equity Ratio, Net Profit Margin berpangaruh secara simultan terhadap Return Saham.

\section{REFRENSI}

Ang, Robert. 2001. Buku Pintar Pasar Modal lndonesia. Mediasoft, Jakarta. Antara, I.M.J., 2012. ... Ratio, dan Price to Earnings Ratio Pada Return Saham Di Bursa Efek Indonesia

Kasmir (2014) Announcements · Home > Vol 14, No 2 (2014) Diaz. TERDAFTAR DI BURSA EFEK INDONESIA.

Rafika - Diaz, Jufrizen — Husnan, Suad. (2010). Manajemen

Suad Husnan dan Enny Pudjiastuti. (2012). Fahmi (2012), ; Earning Per Share (EPS); Net Profit Margin (NPM); ... Harga saham pada periode t. Pt-1 ...

Fahmi dan Yovi Lavianti Hadi (2012:97). — September 2012; Nominal Barometer Riset Akuntansi dan Manajemen 1(2) ... Denies Priantinah .

Ross et al (2000) mendefinisikan free cash flow sebagai kas perusahaan yang dapat didistribusi -

MAHARDIKA, I Nyoman Febri; ARTINI, Luh Gede Sri. PENGARUH RASIO ... E-Jurnal Manajemen, [S.1.], v. 6, n. 4, p. 1877 - 1905, apr. 2017.

Mamduh M. Hanafi dan Abdul Halim. 2005. Analisis Laporan Keuangan. Yogyakarta. Mulyadi. 2001.

Akuntansi Manajemen. Jakarta: Salemba Empat. Munawir,

Sugiyono. 2003. Metode Penelitian. Bandung: Alfabeta. Sugiyono. 2004.

Sugiyono. (2017). Metode Penelitian Kuantitatif, Kualitatif, dan R\&D. Bandung : ... Melalui Penerapan Model Pembelajaran Group Investigation Di Kelas Xi.

Ghozali. (2016). Aplikasi Analisis Multivariete Dengan Program IBM SPSS. Semarang: Badan Penerbit Universitas Diponegoro. Handaru, Agung Wahyu.

Sha, Thio Lie. 2014. Pengaruh ROA, EPS, DER dan NPM Terhadap Pengungkapan Return Saham pada Perusahaan Pertambangan BAtubara yang Terdaftar di BEI. Jurnal Akuntansi Volume XVIII, No. 01, Januari 2014: 86-98. 